\title{
A megfigyelés kutatásmódszertana - Interakciók megfigyelése integrált és inkluzív óvodai környezetben
}

\author{
Böddi Zsófia - Keszei Barbara - Serfőző Mónika - Dúll Andrea \\ ELTE Tanító- és Óvóképző Kar; ELTE Neveléstudományi Intézet Neveléstudományi Doktori Iskola \\ - ELTE Pszichológiai Intézet Pszichológiai Doktori Iskola; BGF KVIK Üzleti Szakoktató és \\ Pedagógiai Intézet - ELTE Tanító- és Óvóképző Kar - ELTE Pszichológiai Intézet
}

\begin{abstract}
Az óvodai integráció és inklúzió hatékony vizsgálatának fontos részét képezi, hogy a fejlödési és pedagógiai történéseket a maguk természetes környezetében tanulmányozzuk. Ennek célravezető módszere lehet a megfigyelés, amellyel akár olyan momentumokat is megragadhatunk, mint a gyermek-gyermek és a gyermekpedagógus interakciók. Jelen tanulmányunkban a megfigyelés kutatás-módszertani hátterének bemutatását követően ismertetjük a gyermeki viselkedés megfigyelésének néhány lehetséges módszerét. Majd áttekintjük és elemezzük az óvodai integráció, inklúzió témájában végzett megfigyeléses vizsgálatokat. Írásunkban kiemelt szerepet kapnak az interakciók megfigyelését célzó tanulmányok, hiszen az óvodai integráció és inklúzió tanulmányozása terén kulcsfontosságú elemnek tartjuk a résztvevők megfigyelését természetes környezetükben, azaz a csoportszobában. Elemzésünkbe tényezőként bevontuk az óvodai környezet összetevőit is, mivel az interakciók ebben a közegben valósulnak meg, illetve maga a környezet elrendezése is hatással van rájuk. A fenti szempontokat a pedagógiai munka tudatossága és tervezése vonatkozásában is érdemes körültekintően elemezni.
\end{abstract}

Kulcsszavak: megfigyelés, interakciók, óvoda, integráció-inklúzió, óvodai környezet

Az emberi viselkedés, különösen a gyermekek viselkedésének kutatási szempontú tanulmányozása mindig nagy kihívás. Cikkünkben a kutatási módszerek között méltánytalanul háttérbe szoruló megfigyelés módszeréről írunk. Tesszük ezt azért, mert a gyerekekkel foglalkozó vizsgálatokban nagy jelentősége lehet a viselkedés, a történések elemi, közvetlen megismerésének. A megfigyelés módszere alkalmat ad arra, hogy a felnőtt (pedagógus, szülő) értelmezése nélkül is információkhoz jussunk egyegy pszichológiai jelenség, pedagógiai helyzet vizsgálatában. Olyan momentumokat is megfigyelhetünk, amelyeket a közvetlen környezet spontán módon nem vesz észre, nem ötlik a szemébe vagy egyszerüen nem fókuszál rá - így verbális kikérdezéssel nem tudna róla beszámolni.

Tanulmányunkban először a kvalitatív megközelítés föbb sajátosságait, majd a megfigyelés módszerének általános jellemzőit foglaljuk össze. Megmutatjuk, hogy a kvalitatív vagy kevert stratégiájú kutatásokhoz hogyan illeszkedhet a választott módszerünk. Ezt követően a gyermeki viselkedés tanulmányozásának jellegzetességeiről írunk az óvodás korosztályra összpontosítva. Kiemeljük az interakciók megfigyelését, valamint az ökológiai és környezetpszichológiai megközelítés szerepét, eszközeit. Utóbbi sok új aspektust adhat az óvodai, csoportszobai történések alaposabb feltárásához és mélyebb megértéséhez. 
Az óvodai nevelés egyik kiemelkedő témája napjainkban a sajátos nevelési igényü (SNI) gyermekek ${ }^{1}$ nevelése, fejlesztése és az integráció, inklúzió ${ }^{2}$ problémaköre. Az együttnevelés mellett szóló érvek között hangsúlyosan megjelenik a gyerekek egymás közti és pedagógussal való interakcióinak kedvező alakulása. A megfigyelés módszerére összpontosító tanulmányunk kiemeli az óvodai csoportban folyó integrált nevelés apró(nak tűnő), mégis kulcsfontosságú mozzanatait. Megmutatjuk, hogy a megfigyelés módszerével hogyan lehet ezeket „mikro szinten” vizsgálni, közvetlen adatokkal alátámasztani. A példaként hozott, bemutatott vizsgálatokban itt is hangsúlyos szerepet kap a környezeti aspektusok elemzése, a viselkedés környezeti kontextusban való tanulmányozása is.

Tanulmányunk hasznos lehet kutatás-módszertani aspektusból, gyerekek viselkedésének tanulmányozásával foglalkozó kezdő kutatóknak. Szeretnénk számukra átfogó képet adni a megfigyelés módszeréről, jellemzőiről, előnyeiről és nehézségeiről. Írásunk továbbá pedagógusoknak is szól, hogy lássák, hogyan használhatják saját munkájuk tudatosabb elemzésében a céltudatos, tervszerủ megfigyelést. A tudományos célú megfigyelés kritériumainak és folyamatának mélyebb megismerése segítheti, hogy a gyakorlatias célok érdekében alkalmazott megfigyelés is objektívebb, megbízhatóbb legyen. Az integráció, inklúzió gyakorlata, kimutatható hatása iránt érdeklődők számára a példaként hozott kutatások módszerei és eredményei lehetnek fontosak és tanulságosak.

\section{Kutatási stratégiák}

\section{Kvantitatív és kvalitatív kutatási stratégia}

A társadalomtudományok történetében a párhuzamosan kialakuló, sőt gyakran szemben álló tudományelméleti, filozófiai megközelítések eredményeképpen jöttek létre az eltérő kutatás-módszertani megközelítések is. A legelterjedtebb a kvalitatív és kvantitatív kutatási stratégiák megkülönböztetése, melyet az alábbiakban Szabolcs Éva (2001) és Szokolszky Ágnes (2004) összefoglalói alapján mutatunk be röviden.

A kvantitatív kutatási megközelítés felfogásában a valóság, a világ objektív, törvényei empirikusan vizsgálhatóak. A világról alkotott tudásunk az igazolt hipotézisekkel, predikciókkal és az ok-okozat feltárásával bővül (habár léteznek leíró jellegü kvantitatív kutatások is). Ennek megfelelően a tényeket és az értékeket külön kezeli, törekszik az értéksemlegességre. Eredményeit általánosításra használja. Módszerei ezzel összefüggésben nagy mintás vizsgálatokban hatékonyak. Hangsúlyos az operacionalizálás, középpontjában a mérés, a mérhetőség, a statisztikai elemzés áll. A „szigorúságából”, objektivitásából fakadóan a kutató és alanya között távolság van, különállónak tekintendők, a kapcsolatuk aszimmetrikus, tehát a kutató irányít, bár természetesen a vizsgálatban résztvevő sze-

\footnotetext{
1 „sajátos nevelési igényű gyermek, tanuló: az a különleges bánásmódot igénylő gyermek, tanuló, aki a szakértői bizottság szakértői véleménye alapján mozgásszervi, érzékszervi (látási, hallási), értelmi vagy beszédfogyatékos, több fogyatékosság együttes előfordulása esetén halmozottan fogyatékos, autizmus spektrum zavarral vagy egyéb pszichés fejlődési zavarral (súlyos tanulási, figyelem- vagy magatartásszabályozási zavarral) küzd" (2011. évi CXC. törvény a nemzeti köznevelésről). Tanulmányunkban a fentiek alapján értelmezzük a sajátos nevelési igényt.

${ }^{2}$ Az integráció fogalmán azt értjük, hogy a sajátos nevelési igényü gyerekek beilleszkednek a nem sajátos nevelési igényü, „ép” gyermekek közösségébe (Illyés, 2000 idézi Köpatakiné, 2004). Az inklúzió, a befogadás fogalma ehhez képest (röviden) annyiban más, „több”, hogy nem csak beillesztik az SNI gyerekeket az intézménybe, annak meglévő rendszerébe, hanem maga az intézmény alkalmazkodik, újratervezik a kereteket és a feltételeket úgy, hogy mindenki számára megfelelő legyen (Sebba, 1996 idézi Kőpatakiné, 2004).
} 
A megfigyelés kutatásmódszertana - interakciók megfigyelése integrált és inkluzív óvodai környezetben

mély nincs kiszolgáltatott állapotban. A kutatás magyarázatai a tapasztaltakból erednek, a levezetések deduktív módon történnek. Az ilyen jellegü kutatást bemutató publikáció személytelen stílusú, kötött felépítéssel rendelkezik (Szabolcs, 2001; Szokolszky, 2004).

Ezzel szemben a kvalitatív metodológia valóságértelmezése holisztikus, szubjektív, a valóságot társadalmi konstrukciónak tekinti, így a világot értelmezendő „alkotásnak”. A kutatás nem feltétlenül hipotézisekkel, inkább nyitott kérdésekkel indul, a hipotézisek - ha vannak - tágabbak, kevésbé specifikusak. A hangsúly a világ, a jelenségek feltárásán, bemutatásán van, igyekszik sokrétüen, több nézőpontból megtenni azt. A „menet közben” felmerülő kérdéseket nem problémaként kezeli, hanem azokra támaszkodik, épít, a témakör megismerésének fontos részét képezik. Nem törekszik az értéksemlegességre, inkább értékorientált. Módszereire jellemző, hogy kisebb elemszámmal, akár egyedi esetekkel dolgozik, középpontjában elsősorban nem a statisztikai elemzés és a mérhetőség áll. $A z$ elemszám ugyan általában alacsonyabb, mint egy kvantitatív kutatás esetében, a vizsgálati idő mégis hosszabb, mivel a kutatást befolyásolják a közben felmerülö kérdések, illetve a kontextus alapos vizsgálata. A kutató és a vizsgálati személy közötti kapcsolat kevésbé aszimmetrikus és formális. Interakcióban állnak, nem elválaszthatóak egymástól, a vizsgálati személy aktív részvevőnek tekintendő. A kutatás magyarázatai a kontextustól függnek, ahhoz kapcsolódnak, maga a kutatás is induktív jellegü. A fenti módon végzett kutatást bemutató publikáció stílusa személyesebb, felépítése kevésbé szigorú, következtetései lehetnek narratív leírások vagy értelmezések (Szabolcs, 2001; Szokolszky, 2004).

Röviden összegezve tehát a kétféle megközelítést:

A kvantitatív kutatási stratégia Szokolszky Ágnes (2004) meghatározása szerint: „Az a kutatási stratégia, amelyik előzetesen rögzített, jól behatárolt változókkal dolgozik valamilyen specifikus hipotézis megerősítése vagy a predikció érdekében. Jellemzőek a mérések, a nagyobb elemszámú minta és a statisztikai feldolgozás" (Szokolszky, 2004, 596. o.). A kvalitatív kutatási stratégia: „Alapvetően induktív kutatási stratégia, amelyik feltáró-jellegű nyitott kérdésekkel indul, kontextusba ágyazott „sűrü” leírásra törekszik, egyszerű mérést és kisebb elemszámú mintát alkalmaz. Jellemzője a folyamat közben alakuló jelleg, a kutatási kérdés és a hipotézis fokozatos kialakulása" (Szokolszky, 2004, 596. o.).

Bár a kvantitatív és a kvalitatív kutatási stratégia egymás „ellentettjeként” jött létre, bizonyos megközelítések pl. a konstruktivista tudományfelfogás követői szerint nem szükséges szétválasztani a kettőt (Szabolcs, 2001). Megfigyelhetők olyan törekvések, amelyekben a kutatásoknál kombinálni igyekeznek a kvalitatív és a kvantitatív stratégiát, törekednek egy integrált kutatás-módszertani modell létrehozására (Sántha, 2009).

Bár a tudományban a kvantitatív vs. kvalitatív szemlélet még mindig jelen van, a nemzetközi szakirodalomban számos ún. „mixed-method” (kevert módszerü) kutatásról olvashatunk, amelyekben mindkét stratégia módszereit alkalmazzák. Li, Marquart és Zercher (2000) beszámol arról, hogy az ilyen, „kevert” kutatások száma növekszik a pedagógiai kutatások, elemzések és a korai intervenció területén is. A fent említett szerzők tanulmányukban az általunk is vizsgált integráció, inklúzió témában végzett „mixed-method” kutatások elemzésének megközelítéseit mutatják be részletesen, lépéseken át. Olyan vizsgálatokat elemeznek, amelyekben kevert módszerekkel gyűjtöttek adatokat az óvodai ${ }^{3}$ inklúzió aspektusairól (Li, Marquart és Zercher, 2000).

\footnotetext{
${ }^{3}$ A hazánkban óvodásnak számító (3-6,7 éves) gyermekek az egyes országok oktatás-nevelési rendszerében különböző intézménytípusokba járhatnak. A továbbiakban minden óvodáskorú gyermeket nevelő intézményt (általában „preschool” kifejezést) óvodának fordítunk.
} 
A hazai szakirodalomban is találunk olyan kutatást, amely komplexen, több módszerrel igyekszik feltárni az óvodai integráció, inklúzió helyzetét. Ilyen A küszöbön Sajátos nevelési igényű gyerekek az óvodákban c. kötet (Kőpatakiné, 2008), amely egy olyan kutatási projektet mutat be, amelyben különböző kutatási módszerekkel (pl. fókuszcsoportos beszélgetések, kérdőíves vizsgálat) igyekeztek körüljárni a témát (Kasza, 2008).

Kiegészítésként megjegyezzük, hogy - bár a társadalomtudományi kutatási módszerek kvalitatív-kvantitatív felosztása alapvető -, érdekes azt is szemügyre venni, hogy a módszereket másként is lehet csoportosítani, azon tudományág sajátosságaitól, perspektívájától függően, amely alkalmazza azokat. A fejlődéslélektan módszereit tekintve például Mönks és Knoers (2004) általános és speciális módszereket különít el. Az előbbi csoportba tartozó módszerekkel a fejlődés egészével vagy bizonyos aspektusaival kapcsolatban bővül a tudásunk, az utóbbi csoport módszerei, technikái a fejlődések jelenségek feltárására hivatottak. Az általános kutatási módszerekhez sorolja a hosszmetszeti (longitudinális) és a keresztmetszeti módszereket, illetve a kohorsz elrendezést, a hossz- és keresztmetszeti vizsgálatok kombinációját. Emellett ebben a csoportban találjuk még a kultúrközi kutatást is. A másik nagy kategória a speciális módszereké, amelyek tovább bomlanak kísérleti és nem-kísérleti módszerekké, utóbbiban találjuk pl. a megfigyeléseket, a klinikai módszert, kérdőívet, interjút stb.

A gyakorlati alkalmazás felöl közelítve a pszichológia módszereihez találkozhatunk még a kutatási és vizsgálati módszerek megkülönböztetéssel is (pl. Keményné, 2006). Eszerint a kutatási módszerek a tudományos megismerés módszerei, újabb igazságok feltárására, hipotézisek igazolására alkalmasak; míg a vizsgálati módszerek célja konkrétabb helyzetek, a viselkedés megértése, a diagnózis, egy-egy gyerek, csoport megismerése. Ez alapján bizonyos módszerek (pl. megfigyelés, rajzelemzés stb.) akár kutatási, akár vizsgálati célokat is szolgálhatnak a konkrét helyzettől, kontextustól és kérdésfeltevéstől függően.

\section{A kvalitatív kutatás jellemzése}

A kvalitatív megközelítés szubjektívebb, „megengedőbb”, más nézőpontból tekint a kutatás egész folyamatára, mint ahogy azt a kvantitatív megközelítés teszi. Bár számos kérdés még nyitottnak tünik, például, hogy hogyan határozhatjuk meg a kvalitatív kutatások metodológiai követelményeit, alkalmazhatjuk-e rájuk, és ha igen, milyen módon a kvantitatív kutatások módszertani kritériumait stb. (Sántha, 2007). Összességében a kvalitatív kutatások mára éppúgy elfogadottá váltak, mint a kvantitatív szemléletben végzett vizsgálatok.

A kvalitatív kutatásmódszertan szakirodalma igen széleskörü. Az átfogó kutatásmódszertani könyveken kívül (pl. Szokolszky, 2004), megjelentek kifejezetten a kvalitatív kutatásokkal foglalkozó müvek is (pl. Szabolcs, 2001; Sántha, 2006, 2009). Megismerhetjük a kvalitatív jellegü kutatások főbb elveit, módszereit, kidolgozták a mintavétel (ld. Sántha, 2006) és az adatfeldolgozás módszereit (Szabolcs, 2001; Sántha 2009).

A kvalitatív kutatások egyik, ha nem a legismertebb elméleti modellje a Glaser és Strauss nevéhez füződő ún. grounded theory vagy „alapozott elmélet” módszer. Ez a modell tulajdonképpen keretet ad a kutató gondolkodásának, rendszerbe foglalja azt, mindamellett, hogy az elmélet- és modellalkotáshoz szükséges, lehető legnagyobb szabadságot nyújtja számára. A modell alkalmazása során három fázist különíthetünk el (Szokolszky, 2004 alapján bemutatva): (1) Az adatok felvételével párhuzamosan elkezd- 
A megfigyelés kutatásmódszertana - interakciók megfigyelése integrált és inkluzív óvodai környezetben

jük a kategóriák fejlesztését is, hogy az adatokat rendszerezni tudjuk, és tartalmukat megvilágíthassuk. (2) Folytatjuk az adatok gyűjtését (az ún. „telítésig”), hogy megvizsgálhassuk, elemezzük a kategóriákat, alakíthassuk és fejleszthessük a kategóriarendszert addig, amíg már nem vetődnek fel újabb kérdések, és a kialakított rendszer összhangban lesz az adatokkal. (3) Egy általánosabb elméleti szisztémába foglaljuk a létrejött kategóriákat, és kiterjesztjük egyéb kontextusra is (Szokolszky, 2004). Tehát „...Az alapozott elmélet" (grounded theory) lényegében kísérlet arra, hogy elmélethez jussunk a megfigyelési adatokban felfedezett mintázatok, témák és közös kategóriák elemzéséből" (Babbie, 2003, 327. o.). A modell lehetőséget nyújt a kutatónak, hogy egyszerre lehessen tudományos, ugyanakkor kreatív is. Ehhez három vezérelvet kell követnie: (1) időnként hátralépni, és kritikai kérdéseket feltenni magának (pl. amit tapasztal, összhangban van-e az adatokkal), (2) a szkepticizmus megőrzése és (3) a kutatási eljárások követése. Az eljárások a kutatás következetességének tényezői, de emellett segítenek elkerülni a torzításokat, és az adatok nem a valóságot reprezentáló értelmezését. (Babbie, 2003)

Bár vannak kutatási módszerek, amelyeket inkább „kvalitatívnak” tekintünk, korántsem biztos, hogy kizárólag kvalitatív kutatásokban jelennek meg. Egyes módszerek megjelennek a kvantitatív kutatásokban is, csak más formában. Például az általunk részletezendő megfigyelés módszerét a kvantitatív kutatásokban is alkalmazzák előkutatásokban, hiszen pl. kérdőívek elkészítésekor a megfigyelések által tudnak elözetes információkhoz jutni a kutatók (Szabolcs, 2001).

A kvalitatív módszerek áttekintésére egyelőre nem létezik egy elfogadott csoportosítás (Sántha, 2009), ezért jelen tanulmányban sem törekszünk átfogó bemutatásra, pusztán a kutatási stratégiáról nyújtandó összegzés céljából emelünk ki néhányat. Sántha Kálmán (2009) a gyakran alkalmazott módszerek és technikák között a támogatott felidézést, a kognitív térképet, a metaforakutatást, az interjú módszerét és az ún. beavatkozás nélküli vizsgálatokat említi. Szokolszky (2004) átfogó kutatás-módszertani munkájában a kvalitatív stratégia fejezetében a természetes megfigyelést, a kvalitatív interjút, a szövegelemzést és az esettanulmányt részletezi.

\section{A megfigyelés mint kutatási módszer}

„A megfigyelés nem más, mint irányított észlelés, amelynek alapján valamilyen megállapításra jutunk" (Szokolszky, 2004, 421. o.). Ez a legalapvetőbb módja annak, hogy információhoz jussunk a jelenségekről. Tulajdonképpen tágabb nézőpontból minden kutatási módszert tekinthetünk egyfajta megfigyelésnek, ha azonban szükebben vizsgáljuk, akkor a közvetlen természetes megfigyelés fogalmát kell értelmeznünk. Ez a módszer a viselkedést abban a formában igyekszik megragadni, ahogy az természetes formában létezik. A vizsgálat során a megfigyelő közvetlen kapcsolatban áll a megfigyelése tárgyával. A definíció kulcseleme - a közvetlenségen túl - az, hogy a megfigyelés során nem vagy csak alig avatkozunk be a megfigyelt folyamatba, szemben például a kísérlettel, ahol a kutató manipulálja a független változót, ami hat a kísérleti személy viselkedésére. A megfigyelés elsősorban leíró, feltáró kutatásokban hasznos módszer, ok-okozati magyarázatok adására nem alkalmas. S bár elsőre nagyon szubjektív módszernek tủnhet, ugyanúgy törekedhetünk a tudományosságra a megfigyelésnél is. „A megfigyelés osztja a többi kutatási módszerrel azokat a jellegzetességeket, amelyek alapján tudományos tevékenységnek számít: céltudatos, tervszerü, és szisztematikusan felépített folyamat, amely érvényes és megbízható adatokat eredményez" (Szokolszky, 2004, 423. o.) Falus Iván (2004) is azt emeli ki, hogy a tudományos megfigyelés célorientált, tervszerü, rendszeres, az objektív tények megfigyelésére irányul. 
A megfigyelés módszerét számos társadalomtudomány (pl. a pszichológia, a pedagógia, a szociológia) és határtudományaik (pl. az antropológia) is alkalmazza, mindegyik természetesen a maga tudományára, metodikájára szabja a módszert.

A megfigyelés alapkérdéseit - Mi a célja? Kit? Mit? Hol? és Hogyan? - a következőképpen lehet összegezni:

1. Cél, azaz mi a megfigyelésünk célja. Ez lehet exploráció, szisztematikus viselkedésleírás, elméletünkhöz kapcsolódóan hipotézis tesztelése vagy más módszerrel történő kombinálás, pl. kiegészítésként vagy a kutatás érvényességének érdekében (Id a korábban említett kevert módszerü (mixed-method) megközelítéseket).

2. Kit, azaz kiket figyeljünk meg (mintavétel).

3. Mit, azaz pontosan mi legyen az a viselkedés, amire a megfigyelésünk irányul. Itt felvetődik, hogy milyen mértékben szelektáljunk (azaz szükítsük a megfigyelendő kérdéskört); mennyire részletezően írjuk le a viselkedést és az értelmezésterheltség, vagyis, hogy mennyire szükséges interpretálnia a megfigyelőnek a tapasztaltakat, ami továbbvezet a szubjektivitás kérdéséhez (Szokolszky, 2004). A megfigyelés egységei Falus Iván (2004) szerint lehetnek konkrét egységek (low-inference item), amikor a megfigyelhető viselkedés legkisebb egységeinek rögzítésére törekszünk. Ez a megfigyelőtől kevés értelmezést igényel, megbízhatóbban rögzíthető, de jobban feldarabolja a valóságot. Az elvont egységek (high-inference item) választása esetén a megfigyelőnek valamennyire interpretálnia kell a látottakat, és bár ezek közvetlenebbül észlelhetők, a különböző megfigyelők közti egységes értelmezés biztosítása nehezebb.

4. Hol, azaz hol végezzük a megfigyelést, laboratóriumi megfigyelés legyen vagy inkább a természetes környezetében figyeljük meg a viselkedést?

5. Mikor végezzük a megfigyelést?

6. Az egyik legkomplexebb kérdéskör, hogy hogyan történjen a megfigyelés: mi a megfigyelő szerepe, mennyire aktív-passzív, részt vesz-e a történésekben, illetve hogyan gyüjti az adatokat (Szokolszky, 2004).

\section{A megfigyelö szerepe}

A megfigyelő státuszát tekintve beszélhetünk nyílt megfigyelésről, amikor a megfigyeltek tisztában vannak a megfigyelő szerepével, de létezik rejtett megfigyelés is, ami azonban etikai kérdéseket vet föl, hiszen eltitkolja a megfigyeltek elöl a kutatás tényét, illetve a saját szerepét. A részvételt tekintve beszélhetünk nem részt vevő, tulajdonképpeni kívül maradó megfigyelésröl (Id. pl. a detektívtükör mögül történő vizsgálatokat) és résztvevő megfigyelésröl. Ez utóbbi történhet rejtetten vagy nyíltan, és a passzivitás-aktivitás dimenziójának valamelyik pontján aszerint, hogy mennyire van interakció a megfigyelő és a megfigyeltek között (Szokolszky, 2004). Babbie (2003) hívja fel a figyelmet a megfigyelő szerepéből fakadó dilemmákra. A terepkutatásban a megfigyelő részvételi fokának eldöntése nem egyszerü kérdés. Az egészen résztvevő megfigyelő lehet valódi résztvevő, vagy tettetheti is, hogy az. Ez azonban szintén felvet etikai kérdéseket, hiszen valójában ebben az esetben megtéveszti a vizsgálat résztvevőit. Az etikai aspektuson túl a részvételnek tudományos hatása is van, hiszen a megfigyelő résztvevő „mivolta” befolyásolhatja a megfigyeltek viselkedését, reakcióit, ill. a történéseket. A megfigyelő kutatónak ennek tudatában kell lennie. Az egészen résztvevő megfigyelő helyett a megfigyelő választhat más szerepet. Például határozhat úgy, hogy bár résztvevő megfigyelő lesz, egyértelművé teszi, hogy kutató. Ennek is lehet viselkedést befolyásoló hatása, hiszen az alanyok tudják, hogy megfigyelik őket, illetve előfordulhat, hogy a kutató túlságosan azonosul a csoporttal, és már nem tudja tartani a megfelelő „kutatói távolságot” (Babbie, 2003). Ugyanakkor több kutatás 
A megfigyelés kutatásmódszertana - interakciók megfigyelése integrált és inkluzív óvodai környezetben

is kimutatta, hogy a résztvevők meg tudnak feledkezni a megfigyeltség tényéről még olyan extrém esetekben is, amikor egy készüléket hordanak magukkal (pl. hangfelvevő, mely bizonyos időközönként felveszi a vizsgálati személyek beszélgetéseit) (Mehl és Holleran, 2007 idézi Mehl és Robbins, 2014).

Részvétel szempontjából a másik véglet a fent említett egészen megfigyelő, azaz a nem résztvevő megfigyelő, azonban ez is felvet kérdéseket, hiszen a nagy „távolság", a tartózkodó megfigyelés miatt előfordulhat, hogy kevésbé árnyalt képet lát. $A$ megfigyelő részvételével kapcsolatos másik megfontolandó elvi kérdés a megfigyeltekhez füződő viszony, és annak potenciális hatása (Babbie, 2003).

\section{A megfigyelés módja, azaz a „Hogyan?”}

A megfigyelés módjához kapcsolódik annak strukturáltsága, kötöttsége is. Strukturált megfigyelést alkalmazva elöre definiáljuk a változókat, a megfigyelés kötött, standardizált, objektív. A megfigyelő meghatározott szabályokat alkalmaz a megfigyeléskor, egy jól definiált kategóriarendszert használ a viselkedés leírására. Egy ilyen kategóriarendszer kidolgozása munkaigényes folyamat: megalkotjuk a kategórianeveket és a jelölőkódot, a kategóriák pontos definícióját, bemutatunk példákat, érvényesítjük az inkluzivitás (minden látható viselkedést be kell tudnunk sorolni valamelyik kategóriába) és exkluzivitás (a kategóriák nem lehetnek átfedőek) követelményét, végül pedig kidolgozzuk az egyéb szabályokat. A kategóriarendszer elkészülte után azt is meg kell határoznia a kutatónak, hogy a megfigyelés mit vegyen alapul: esemény- vagy időegységet. Léteznek egyéb technikai eljárások a megfigyelés esetében, ilyen a jelrendszer vagy a becslési skála alkalmazása.

A strukturálatlan megfigyelés sem jelent teljes kötöttségmentességet, előzetes szempontok és célok vezérlik, azonban nincs egy kötött, szigorú kategóriarendszere. Megfigyeléses vizsgálatban a strukturáltság foka is eltérő lehet (Szokolszky, 2004).

\section{A megfigyelés érvényessége és megbízhatósága}

A megfigyeléses vizsgálatokkal szemben is követelmény - akár inkább kvantitatív, akár inkább kvalitatív „,irányból” közelít -, hogy kellően tudományos legyen.

A strukturált megfigyelésekkel szemben, akárcsak a többi kutatási módszer esetében, követelmény az érvényesség (validitás, azaz az arra vonatkozó kritérium, hogy tényleg azt mértük-e, ami a szándékunkban ált, tehát a kutatási folyamatok megfelelőségére utal) és a megbízhatóság (reliabilitás, azaz a mérés stabilitása, vagyis ha megismételnénk azt, (közel) ugyanazt az eredményt kapnánk-e).

A megfigyelés esetében - kvantitatívabb nézőpontból - az érvényesség egyrészt azt jelenti, hogy a megfigyelés valóban a valóságról „szól-e”, nem torzítja-e azt. Ide kapcsolódik a megfigyelő elfogultságának kérdése, amit igyekeznünk kell kiküszöbölni, pl. azzal, ha videóra vesszük a megfigyelt jelenséget. Gond lehet a reaktivitás, vagyis, hogy minél feltűnőbb a megfigyelés, annál inkább „reagálnak rá”, vagyis a kamera jelenlétére, a megfigyelés tudatában másképp viselkednek a megfigyelt személyek. A reaktivitást is tudjuk csökkenteni azzal, ha minél kevésbé tesszük feltűnővé a megfigyelést, vagy nem mondjuk meg egészen pontosan, mit vizsgálunk, így a speciális válaszok elkerülhetőek, illetve a hozzászoktatással. Másik szempontból tekintve az érvényességhez kapcsolható az is, hogy a kutató által meghatározott kategóriák valóban megfelelően reprezentálják-e a vizsgált fogalmat. Végül ide kapcsolódik még az ökológiai validitás, azaz, hogy mennyire általánosíthatóak az eredmények a természetes körülményekre. 
Laboratóriumi megfigyelés esetében az ökológiai validitás alacsony lehet, míg a validitás más aspektusai és a reliabilitás magas lehet, ezzel szemben egy természetes megfigyelés esetében az ökológiai validitás magas, de más jellemzők mentén nem feltétlenül lesz erős a vizsgálat.

Falus (2004) az alábbi módon részletezi a validitás fogalmát, amely többféle szempontból értelmezhető:

- funkcionális vagy konstrukciós validitás: ami azt jelenti, hogy a kategóriák alkalmasak a viselkedések megkülönböztetésére

- elméleti (tartalmi) validitás: a megfigyelés kategóriarendszere az adott elméletnek megfelelő

- empirikus vagy egyetértésen alapuló validitás: más méröeszközökkel is ugyanolyan képet kapunk az adott jelenségről

- elörejelző (prediktív) validitás: az eszköz képes olyan mennyiségek, minőségek megkülönböztetésére, amelyek előrejeleznek a későbbiekben bekövetkező különbségeket (pl. a tanítási folyamatban a tanár viselkedésének különbsége pl. a gyerekek bevonása tekintetében előrejelzi a gyerekek későbbi problémaérzékenységében, problémaközpontú gondolkodásában megjelenő különbségeket) (Falus, 2004).

A megbízhatóság a megfigyelésnél arra utal, hogy precízen és megfelelően azonosítják-e a megfigyelt viselkedést. Ezt a megfigyelők közötti egyetértés mértékének kiszámításával követhetjük nyomon. A vizsgálat megbízhatóságát igazolhatjuk, ha egy független megfigyelő is kódolja a vizsgálati anyag egy részét, és a két megfigyelö közötti eltérés kismértékủ (Szokolszky, 2004). Többféle módon lehet jellemezni a megbízhatóságot: fókuszba helyezhetjük az ugyanabban az időpontban több megfigyelő vagy független elemző közötti egyetértés mértékét, vizsgálhatjuk a különböző időpontokban végzett megfigyelések közötti eltérés mértékét (stabilitást), illetve a különböző időpontokban, különböző megfigyelők tapasztalatai közötti eltérés mértékét (Falus, 2004).

Az érvényesség és a megbízhatóság kérdéskörének kvalitatív nézőpontja a megfigyelésről elismeri a kutató, megfigyelő nézőpontjának, interpretációjának, esetleges szubjektivitásának fontosságát, jelenségét, ugyanakkor korántsem önkényes elemzésről van szó, hangsúlyos a pontos, átlátható dokumentáció, az alapos adatelemzés és hogy pl. más módszerekkel érvényesítsük a kutatást (Szokolszky, 2004).

A megfigyeléses vizsgálatok tervezésekor a fentieken kívül érdemes egyéb szempontokat, kérdéseket is megfontolnunk a kutatás kivitelezhetősége érdekében. Héra és Ligeti (2014) a terepen végzett gyakorlati munka, megfigyelés esetében az alábbiakat javasolja. Az egyik első lépés, hogy kiválasztjuk a terepet. Ezután érdemes magunknak feltenni az alábbi kérdéseket, és meg is válaszolni azokat:

- „Biztosan alkalmazhatjuk-e a megfigyelés módszerét?

- Hogyan határolható be az adott helyszín?

- Milyen kapcsolatban vagyunk az adott helyszínnel? Kik vagyunk mi ott? Milyen már létező kapcsolataink vannak a terepen élőkkel/dolgozókkal?

- Hogyan juthatunk el a helyszínhez?

- Milyen etikai és jogi kérdések merülnek fel a terepen?

- Mit mondjunk a kutatás résztvevőinek a kutatásról?

- Milyen sztereotípiák élnek bennünk azokról az emberekröl, akiket a helyszínen találunk?

- Hogyan alakíthatunk ki kapcsolatot a terepen élőkkel?" (Héra és Ligeti, 2014. 119-120. o.)

Ezek és az ehhez hasonló kérdések segíthetik a kutatót, hogy milyen szempontokat gondoljon végig magában a megfigyelés módszerének választása előtt. 
A megfigyelés kutatásmódszertana - interakciók megfigyelése integrált és inkluzív óvodai környezetben

\section{A gyermeki viselkedés tanulmányozása}

A gyermekek - föként, ha fiatalabb életkorra gondolunk - tanulmányozása különleges, más metodikát igényel. A csecsemőket nem tudjuk megkérdezni ahhoz, hogy egy-egy pszichológiai jelenséget tanulmányozzunk, és a nagyobb gyerekeknél is korlátozott a szó- vagy írásbeli megkérdezés lehetősége. Az írásbeli technikák jelentősége háttérbe szorul, de szóbeli kikérdezéseket is csak megkötésekkel alkalmazhatunk: figyelembe kell vennünk a gyermek verbalitásának fokát, és meg kell találnunk azt a csatornát, technikát, amellyel feltérképezhetjük a gyermek gondolat- és érzelemvilágát. Bár léteznek ilyen módszerek (pl. Piaget klinikai módszere), illetve kifejleszthetünk magunk is egy-egy szóbeli kikérdezésen alapuló eljárást (Böddi és B. Lakatos, 2010), más jellegű információhoz jutunk megfigyelések végzése által. Mi sem bizonyítja jobban a gyermekek tanulmányozásában a megfigyelés fontosságát, hogy gazdag szakirodalmi anyag, módszer, kutatási elrendezés áll rendelkezésünkre a gyermekek megfigyelésével kapcsolatosan.

A következőkben a teljesség igénye nélkül áttekintjük a gyermeki viselkedés megfigyelésének módszereit. A korai megfigyelésektől kezdve a legmodernebb technológiákig hoztunk példákat a megfigyelés lehetséges módjaira. Jelen tanulmányban nem célunk történeti áttekintést nyújtani a gyermeklélektani, illetve a fejlődés-lélektani megfigyelések módszereinek teljes „tárházáról”, pusztán kiemelünk egy-egy momentumot, kutatót vagy kutatást, akik a gyermeki viselkedést helyezték középpontba. Célunk, hogy egy-egy módszer, technika bemutatásával „felvillantsuk” ennek a kutatásmódszertannak a gazdagságát, a vizsgálati elrendezések számos variációját.

A gyermeki viselkedés tanulmányozásának történetében az egyik első állomásnak tekinthetjük azokat a megfigyeléseket, amelyek során kutatók készítettek feljegyzéseket saját gyermekeik fejlődéséről. Az egyik ilyen híres csecsemőnapló Charles Darwiné, aki saját fiáról vezetett naplót. Szintén megemlítendő Jean Piaget, aki alapos részletességgel írt megfigyeléseket gyermekeiről, e feljegyzések nyomán fejlesztette ki a későbbi elméleteit is (Cole és Cole, 2003).

A megfigyelések során különböző speciális eszközöket is alkalmazhatunk. Agyermekek figyelmének követésére használt igen elterjedt módszer a szemmozgás követése, habár természetes környezetben, a mindennapi életben megfigyelhető viselkedés vizsgálatára kevés kutatás használta ezt az eljárást (Franchak, Kretch, Soska és Adolph, 2011). A vizsgálati eszközök egy másik kedvelt családja a gyerekek mozgását, aktivitását mérő eszközök, mint pl. a pedometer vagy az aktometer. A pszichológiai és pedagógiai vizsgálati kérdéseken túl ezek az eszközök egészségmagatartás vizsgálatára is alkalmasak. Egy korai vizsgálat az elérhető, kívánatos játszóterek és a gyerekek aktivitása közötti összefüggéseket vizsgálta. Amennyiben a játszótér közel volt a lakóhelyhez, akkor az iskolások használták is azt, és átlagosan 2-3 mérfölddel többet mozogtak, mint azok a gyerekek, akinek a lakókörnyezetében nem volt könnyen elérhető, megfelelő játszótér (Billings, 1934 idézi, Wilhelm, Perrez és Pawlik, 2014). Az aktometer többek között lehetőséget kínál a mozgás és az intelligencia közötti öszszefüggések feltárására (MacCoby, Dowley és Hagen, 1965 idézi Wilhelm, Perrez és Pawlik, 2014). Az aktivitás követése különösen fontos módszer hiperaktív és figyelemhiányos gyerekek megfigyelése során, akiknél különböző hétköznapi helyzetekben mérhetik az aktivitás mértékét (Teicher, 1995 idézi Bussmann és Ebner-Priemer, 2014). Ezenkívül a hiperaktív gyerekeknek adott nyugtatók hatását is nyomon lehet követni az eszközzel (Johnson, 1971 idézi Wilhelm, Perrez és Pawlik, 2014).

A megszokott, mindennapi környezetben végzett megfigyelések egy új iránya a számítástechnikai eszközökkel felszerelt helyszín. A vizsgálati személy lakó-, vagy 
munkahelyét, vagy akár az oktatási környezetet az aktuális kutatás szempontjából fontos megfigyelési eszközökkel szerelik fel, legyen szó a hőmérséklet és páratartalom monitorozásáról, vagy a vizsgálati személyek mozgásának, aktivitásának lekövetéséről mozgás érzékkelőkkel vagy nyomásérzékeny burkolattokkal, csempével (Orr és Abowd, 2000 idézi Bussmann és Ebner-Priemer, 2014).

A módszer kiválóan alkalmas olyan spontán megjelenő viselkedések megfigyelésére, mint pl. az autizmussal élő gyerekeknél megjelenő sztereotip mozgás. A kutatás során a fentiekhez hasonló technikát használnak a gyerekek viselkedésének monitorozására. Ebben az esetben nagyfelbontású videó és hanganyaggal valamint gyorsulásmérő segítségével gyűjtenek adatot a viselkedések gyakoriságáról, ill. a feltárható mintázatokról. Mivel az autizmus diagnosztizálásában csak viselkedéses jellemzőkre támaszkodhatunk, a zavar korai felismerés szempontjából rendkívül fontos, hogy ezeket a viselkedéses jegyeket mihamarabb felismerjük. A diagnózist általában csak 3-5 éves kor között állítják fel, holott a szülők retrospektív beszámolói alapján tudjuk, hogy bizonyos jegyeket már 2 éves kor körül is meg lehetett figyelni. A kutatás során szerzett adatok hozzájárulnak az autizmus korai felismeréséhez (Goodwin, 2014), így a fejlesztést is korábban el lehet kezdeni.

\section{A gyermekek interakcióinak megfigyelése}

Számos kérdés, kutatási probléma irányul társas helyzetek vizsgálatára, ezekben az interakciók megfigyelése kerül fókuszba. A szakirodalmat tanulmányozva láthatjuk, hogy sok írás foglalkozott és foglalkozik napjainkban is viselkedési, interakciós megfigyelési eljárásokkal

Az egyik leghíresebb vizsgálat a Mary Ainsworth munkájához köthető Idegen Helyzet Teszt, amely a kötődés szempontjából vizsgálja az anya-gyermek interakciót. A csecsemők viselkedésének megragadására laboratóriumi megfigyelést végeznek detektív tükör mögül. Ebben az epizódokra bontott vizsgálati eljárásban a szeparáció, és az anyával, illetve egy idegennel töltött együttlét epizódjai váltakoznak. Az Idegen Helyzet Teszt során mutatott viselkedések megfigyelése alapján sorolják be a csecsemőket kötődési kategóriákba (ld. Ainsworth és Wittig, 1969, idézi Cole és Cole, 2003).

Egy másik - szintén széles körben ismertté vált kutatás a Diana Baumrind (1971, 1980, idézi Cole és Cole, 2003) nevéhez köthető nevelési stílusokról szól. A kutatásban családokat vizsgáltak: egyrészt megfigyelték a gyerekek viselkedését az óvodában, másrészt a gyerekek szüleivel interjúkat készítettek a nevelési stílusukkal kapcsolatban. Ezeken kívül a családok otthonában végeztek megfigyeléseket a szülő-gyermek interakciók tanulmányozása céljából. Az így nyert adatokból megállapítottak háromféle nevelési stílust, illetve összefüggésbe hozták azokat az óvodában megfigyelt viselkedésmódokkal (Cole és Cole, 2003).

A szülö-gyermek interakciók vizsgálata kiemelt szerepet kap a fejlődéslélektanban. Az angol nyelvű szakirodalomban már 1971-ből is találunk például egy áttekintő tanulmányt a szülö-gyermek interakciók tanulmányozásáról a Child Development címü folyóiratban (Lytton, 1971). A szülö-gyermek interakciók megfigyelése, illetve az erre kifejlesztett módszerek elemzése (pl. a megfigyeléses módszerek előnyeinek és hátrányainak mérlegelése, megfigyelés mesterséges vs. természetes körülmények között, a megfigyelő jelenlétére adott reaktivitás stb.) nem csak a tudományos kutatásokban, hanem a klinikumban is hangsúlyos (Gardner, 2000).

Az interakciók vizsgálatának egyik lehetséges modern formája, hogy a vizsgálati személyektöl csak hanganyagot vizsgálunk. Az ún. LENA (Language Environment Analysis/ 
A megfigyelés kutatásmódszertana - interakciók megfigyelése integrált és inkluzív óvodai környezetben

nyelvi környezet elemzés) rendszer segítségével a gyerekek és gondozóik közötti interakciók vizsgálata válik egyszerűen elemezhetővé. A rendszer része egy hordozható felvevő egység, amelyet, ennek az egységnek a tárolására kialakított zsebbe helyeznek el a gyerekek ruháján, így az egész nap velük lehet, és adatot gyüjthet (Warren, Gilkerson, Richards, Oller, Xu és Yapanel, 2010 idézi Hektner, 2014). A módszer használható többek között autizmussal élő gyerekek interakcióinak vizsgálatára is. A kutatási eredmények szerint ugyan az autizmussal élő és a tipikusan fejlődő gyerekekkel ugyanolyan gyakran beszéltek gondozóik, azonban az elöbbiekkel folytatott beszélgetésekben kevesebb szófordulat és több monológ fordult elő (Warren és mtsai, 2010 idézi Hektner, 2014).

\section{Óvodáskorú gyermekek viselkedésének megfigyelése}

A következő fejezetben áttekintést nyújtunk arról, hogy milyen vizsgálatok, módszerek, akár konkrét technikák és kódrendszerek születtek és születnek az óvodás gyermekek viselkedésének, interakcióinak megragadására.

A hazai szakirodalmat tanulmányozva kiemelkedik Mérei Ferenc munkássága, aki munkatársaival számos, a mai napig alapnak tekintendő vizsgálatot végzett óvodás gyermekek körében (is). A viselkedés-megfigyelés terén az aktometria (azaz az tevékenységmérés) módszerét emeljük ki, amellyel az óvodás gyermekek társas interakcióit figyelték meg, megnyilvánulásaikat kódolták. „Az aktometriai regisztrálás a társas viselkedés megfigyelésének, folyamatszerü rögzítésének, formalizálásának és kvantifikálásának a módszere." (Mérei, 1989, 93. o.)

Ez, az elsősorban szociálpszichológiai módszer az alábbiakból áll: „A csoporttörténéseket helyzetekbe tagoljuk, és személyek szerint felbontjuk a cselekvés társas vonatkozásainak a szempontjából. A cselekvési egységeket jellel látjuk el. Az aktusokra bontott viselkedés formalizált társas elemeit mutatókban összesítjük" (Mérei és $V$. Binét, 2006, 136. o.).

Az aktometria egyik komplex kategóriája a tevékenység társas színvonala, mely a csoportbeli társas magatartás jellemzőit foglalja magába. 14 fejlődési formáját írták le a „magányos semmittevéstől” a „szervezett csoporttevékenységig”. Eszerint „az alacsonyabb fejlődési fokot a magányosság és a semmittevés jelzi, a legfejlettebb fokot pedig a részvétel a szervezett csoport szervezett tevékenységében." (Mérei, 1989. 83. o.) Az aktometriai megfigyelés során ezen túl még olyan társas momentumokat is rögzítettek, mint a modellnyújtás, ill. -követés, parancsolás, kezdeményezés, irányítás, támadás, közeledés, tárgyak megszerzése és megtartása (Mérei, 1989).

Óvodásoknál a 14 társas formát egyszerűsítve a csoportosulás öt szintjét/ a csoportképződés öt változatát azonosították megfigyelésen alapuló kutatásaikban: együttlét - együttmozgás - tárgy körüli összeverődés - összedolgozás - tagolódás (Mérei és V. Binét, 2006).

Mérei Ferenc és munkatársai az aktometriát alkalmazták például arra is, hogy kísérleti körülmények között figyeljék meg a gyermekek viselkedését (Id. például az együttes élmény vagy a pár és csoport kísérleteket, Mérei és $V$. Binét, 2006). Az aktometriai megfigyelés alkalmas módszer óvodai csoportok szociometriai felmérésében is. Ebben az esetben a csoport kötetlen együttléte alkalmával készül a megfigyelés (Mérei, 2004).

Amegfigyelés, mint azóvodás gyermek megismerésének módszere más fejlődés-, ill. gyermeklélektani munkákban is egyértelmű jelentőséggel bír. A Fejlődéslélektani vizsgálatok (Kósáné, Járó és Kalmár, 1975) az 1970-es években készült módszergyűjtemény, kézikönyv, amely egyfajta csokor a gyermekek vizsgálatához, fejlődésük kiemelkedő aspektusainak megismeréséhez, tanulmányozásához. Bőséggel tartalmaz 
megfigyeléses módszereket, amelyhez szempontokat és konkrét jegyzőkönyvezési sémákat is kínál, törekszik az objektív megragadhatóságra.

Különleges módszernek tekinthető például a „Mackógyerek egy napja” vizsgálat, amelyet Kürti Istvánné és Szilágyi Lilla (1970) dolgoztak ki. Előzetes vizsgálódásaik tapasztalatainak beépítésével hoztak létre egy vizsgálati helyzetet (óvodások és kisiskolások számára), amelyben a gyermek egy babaszobában kismackók segítségével játssza el a mackógyerek egy napját, annak történéseit. A gyermek játékának megfigyelésére egy alapos kategóriarendszert dolgoztak ki, ennek segítségével lehetséges regisztrálni a gyermek viselkedéses és szóbeli megnyilvánulásait (Kürti és Szilágyi, 1970; Kósáné, Járó és Kalmár, 1975). A vizsgálódás azonban nem korlátozódik feltétlenül pusztán megfigyelésre, mivel a feladatmegoldást tovább is elemezték, a vizsgálat alkalmazhatóságában a személyiséget érintő elemzéseket is végrehajtanak (Kürti és Szilágyi, 1970).

Kifejezetten az óvodára kidolgozott módszergyűjtemény Kósáné Ormai Vera Mi óvodánk c. munkája, amelyben szisztematikusan áttekinti az óvoda tényezőit, résztvevőit, és mindegyik témakörhöz ajánl módszereket, amellyel körüljárhatjuk azt. Itt is bőven találunk megfigyeléses vizsgálatokat, pl. az interakciók, érzelmek terén (Kósáné, 2001).

\section{A környezet gyermeki viselkedésben játszott szerepe}

A fenti felsorolásból is látható, hogy a kutatók kiemelt figyelmet fordítanak a gyermekek óvodában történő interakcióinak tanulmányozására. Azonban az interakciókat, történéseket nem lehet csak önmagukban, „vegytisztán” értelmezni, az emberek és így a gyermekek közötti interakciók nem függetlenek a környezettöl (vö. Dúll, 2009). Kutatások sora foglalkozik annak vizsgálatával, hogy a kontextus hogyan befolyásolja a gyerekek viselkedését (vö. Dúll, 2015). Ezek a munkák felhívják a figyelmet a kontextus fontosságára, fejlődésben betöltött szerepére is.

Ismert, hogy a gyermek későbbi iskolai kimeneteléhez kapcsolódó kompetenciák fejlődésében hangsúlyos szerepe van a kontextusnak és az interakcióknak (a felnőttekkel, a társaival, illetve a tevékenységekkel és eszközökkel) (Booren, Downer és Vitiello, 2012).

A viselkedés ökológiai megközelítésében „a gyerekek fejlődési kontextusai egy a közeli kapcsolatokból álló hierarchiába ágyazottak - mint az egykorú társaik és a pedagógusok -, amely nagyobb rendszerekben helyezkedik el, mint az osztály és az iskola" (Bronfenbrenner 1979, idézi Booren, Downer és Vitiello, 2012. 519. o.).

Egy másik megközelítés (Gump, 1975, idézi Booren, Downer és Vitiello, 2012) szerint a gyermeket körülvevő környezet tartalmaz egy miliőt (a tér vagy a létesítmény) és egy programot (ahogy a dolgokat csináljuk), kiemelve, hogy a legtöbb kontextusnak van egy a gyermeki viselkedésre ható napirendje vagy rendszere. Booren és munkatársai (2012) rámutatnak arra is, hogy a természetes megfigyelés a gyermek viselkedésének és a csoportszobai környezet vizsgálatának megfelelő módszere lehet. Kutatásukban - amelyet abból a szempontból emelünk ki, hogy megfigyeléssel milyen komplex kérdéskört jártak körül - az óvodai tevékenységformákat vizsgálták, az azok során megfigyelhető interakciókat, a nem hatását, illetve az alapvető pedagógusi viselkedésmódokat tanulmányozták. Ehhez szisztematikus megfigyelést végeztek 145 óvodás körében egy kódrendszer segítségével (Individualized Classroom Assessment Scoring System; Egyéni Csoport/Osztály Értékelő Pontozó Rendszer), amely a pedagógussal, a társakkal, a feladatokkal és a konfliktusokkal kapcsolatos interakciókban megfigyelhető viselkedés megragadására képes. Elemezve a tapasztaltakat, képet kaptak az egyes tevékenységtípusokban jellemző interakciófajtákról, így például arra jutottak, hogy a társakkal és a feladatokkal folytatott interakciók pozitívabban alakultak 
A megfigyelés kutatásmódszertana - interakciók megfigyelése integrált és inkluzív óvodai környezetben

a gyermek által irányított tevékenységekben. A tanulmány felveti, hogy ebben a kérdéskörben is érdemes a pedagógusoknak tudatosabbá válniuk (Booren, Downer és Vitiello, 2012).

\section{A környezetpszichológiai megközelítés szerepe a gyermeki viselkedés tanulmányozásában}

A korábban már említett Gump (1975 idézi Booren és mtsai, 2012) megközelítésére rímel a környezetpszichológiai megközelítés, amely a környezet fogalmába a fizikai környezetet is beleérti, sőt, annak a benne levő ágensekkel egyenrangú szerepet tulajdonít. A környezetpszichológiai paradigmára jellemző az ún. tranzakcionalista megközelítés, melynek értelmében az embert és környezetét rendszerben szemléli, szociofizikai környezetről beszél. Az emberi viselkedés és a fizikai környezet, amiben az lejátszódik, kölcsönösen meghatározzák egymást, egymás nélkül nem értelmezhetőek. Az adott cselekvés sohasem értelmezhető a kontextusa nélkül (Dúll, 2001, 2009). Egy kutatás központjában ugyan állhat pl. az interakció vizsgálata, de nem feledkezhetünk meg arról, hogy minden cselekvés, akció egy - bizonyos jellemzőkkel rendelkező pl. világos, tágas, átlátható játékterekre osztott vs. egy sötét, hosszúkás alakú, zsúfolt csoportszoba - fizikai környezetben zajlik, mely hatással van az ott zajló eseményekre és viszont (lásd Dúll, 2015).

Az óvodai környezetben zajló vizsgálatok esetében is érdemes lenne a fizikai környezeti elemekre, az ergonómiai kívánalmakon túlmutatóan figyelmet fordítani. Az óvodai környezetek kapcsán Pálfi Sándor (é.n.) sokat idézett írása kiválóan tükrözi azt a megközelítést, mellyel a környezetpszichológia is vizsgálja a játéktereket. $A$ játéktereket nem csak medernek tekinti, hanem azok kialakításával a játéktevékenység irányításában rejlő lehetőséget is meglátja. Valamint rávilágít arra, hogy a környezetek kialakítása, és ezzel szoros összefüggésben az ott érvényben levő szabályok (pl. ki vehet le a polcról egy játékot stb.) milyen nagymértékben befolyásolják a gyerekek kompetenciáit, azok fejlődését.

Fontos hogy az óvodák berendezésénél ne hagyjuk, hogy az esetleg nehézkes, szükös téri lehetőségek miatt (pl. „oda fért el”) átgondolatlanul, a gyakorlati kritériumoknak nem megfelelő teret hozzunk létre. A tárgyak funkcionális elrendezésével implicit módon vezérelhetjük a tevékenységet és fejleszthetjük a gyerekek képességeit (Nash, 1981 idézi Dúll 2009). A jól használható, jól működő terekben a játékszereket is rendeltetésszerüen használják a gyerekek, kevesebb a verekedés (Pálfi, é.n.), és a környezeti kompetencia fejlesztésére is mód nyílik. Vagyis a gyermek megtapasztalhatja és gyakorolhatja, hogy hogyan tud hatékonyan bánni a környezettel (Pedersen, 1999 idézi Dúll 2009), hogyan tudja kontrollálni és használni a fizikai környezetet, melyben így magabiztosabbá válhat.

Eddig csak a viselkedést említettük, de a térhasználat és a téri kompetenciák kapcsán a térhasználathoz kapcsolódó érzelmi élményröl sem feledkezhetünk meg. Hiszen azokhoz a helyekhez, melyeket sokat használunk - gyerekek esetében ilyen hely lehet az óvoda, az óvodai csoportszoba - vagy amelyhez élmények kötődnek, ahol hatékonynak érezzük magunkat könnyen ún. helykötődés alakul ki. A helykötödés biztonságérzetet ad többek között az adott környezetben gyakorolható kontrollon keresztül (Dúll, 2002, 2009).

Meg kell azonban jegyeznünk, hogy a környezetpszichológiai szempontok figyelembe vételét nagyban megnehezíti, hogy a fizikai környezetünk okozta hatásokat nehéz tudatosítani. A szélsőségeken kívül, pl. nagyon zsúfolt egy helység, nyomasztóan 
alacsony a belmagasság, vagy nem fér el a lábunk az asztalnál, általában nem ismerjük fel, hogy a fizikai elrendezés is felelős a megjelent viselkedésért (Dúll és Urbán, 1997; Dúll 2009).

\section{Az óvodáskorú gyermekek interakcióinak tanulmányozása integrált, inkluzív óvodai környezetben}

Az óvodában történő integrált vagy inkluzív nevelésnek számos tényezője van. Ahhoz, hogy komplex és árnyalt képet kapjunk a témáról, nyilvánvalóan érdemes mindezeket számba venni, és tanulmányozni, elemezni. Az integrációt, inklúziót célzó programok, megoldásmódok eredményességében is meghatározóak a fent említett szempontok: a környezeti tényezők és az interakciók. A megfigyelés módszerére összpontosító tanulmányunk kiemeli az óvodai csoportban folyó integrált nevelésnek azokat az apró(nak tünő), de mégis fontos mozzanatait, amelyeket kulcsfontosságúnak mondhatunk. llyenek például a gyermekek viselkedése, az interakciók a résztvevők között, az óvodai környezet elemei, és a viselkedés ezen kontextusban történő tanulmányozása.

Az óvodai inklúzió témáját tanulmányozva a nemzetközi szakirodalomban számos tanulmányt találhatunk. Ezekben az interakciók megfigyelése is megjelenik, fontos aspektusnak tűnik, hiszen a sikeres inklúziónak ez fontos összetevője lehet, illetve a sikeres inklúzió például a társas kapcsolatokban, interakciókban is megmutatkozik.

Odom (2000) áttekintésében, amelyben leírja az óvodai inklúzióval kapcsolatos 2000-ben aktuális tudásukat (az Amerikai Egyesült Államokban), kitér az interakciókra is. Összegezve azt állapítja meg, hogy inkluzív csoportokban a sajátos nevelési igényü $(\mathrm{SNI})^{4}$ gyerekek a nem SNI gyermekekhez képest kevésbé gyakran részesei a szociális interakcióknak. Ide kapcsolódik az elutasítás vagy épp a szociális készségekhez kötődő intervenciók témaköre is. A szerző felhívja a figyelmet arra, hogy „mivel a szociális integrációt, a szociális kompetenciát és a szociális kapcsolatokat pont olyan kimenetelekként definiáljuk, amelyeket remélünk, hogy fejleszthetünk az SNI gyerekeknél, fontos, hogy megállapítsuk, hogyan mérhetjük fel ezeknek a fejlődését, előmenetelét az egyes gyermekek esetében. Ahogy az is fontos, hogy felmérjük az inkluzív programok általános hatásait is." (Odom, 2000. 21. o.).

Kontos, Moore és Giorgetti (1998) az Inklúzió ökológiája (The Ecology of Inclusion) című tanulmányában a fogalom (és egyben a jelenség) ökológiai megközelítését ismerteti. Különös hangsúlyt fektetnek az egyedi szintre, azaz az inklúzió azon aspektusára, amely az egyéni tapasztalatszerzést érinti. ,...ha figyelmet fordítunk a programszintü változókra és a gyerekek tapasztalataira, segít, hogy felismerjük az inkluzív elrendezések kritikus vonásait, amelyek hozzájárulnak a gyermek fejlődéséhez..... Fontosak azok az adatok, amelyek leírják az SNI gyerekek inkluzív csoportban szerzett tapasztalatait, ha meg akarjuk érteni, hogyan vonjuk be őket a tipikus gyermekkori szabadjáték tevékenységekbe, amelyek az első számú közvetítői a tanulásnak a fejlődés szempontjából megfelelő korai gyermeki környezetben. Ez lehet a része egy járható útnak a korai intervenciós megközelítések között." (Kontos, Moore és Giorgetti, 1998. 38. o.).

\footnotetext{
${ }^{4}$ A szakirodalomban a sajátos nevelési igényű (SNI) gyermekekre más kifejezéseket is találunk, szóhasználatból, hangsúlyokból, a probléma okának azonosításából eredően, pl. fogyatékkal élő gyermekek (children with disabilities). Hazánkban jelenleg az SNI kifejezés terjedt el, így tanulmányunkban az egységesség céljából a fogyatékkal élö, sajátos nevelési igényű stb. gyermekekre a továbbiakban az SNI megnevezést használjuk.
} 
A megfigyelés kutatásmódszertana - interakciók megfigyelése integrált és inkluzív óvodai környezetben

Vizsgálatuk célkitúzését, azaz, hogy a gyermekek szabadjáték során szerzett tapasztalatszerzését ismerjék meg, a pedagógiai gyakorlatra futtatják ki: „A gyermekek által szerzett tapasztalatok kontextusának alaposabb megismerése révén az elméleti és gyakorlati szakemberek kedvezőbb helyzetbe kerülnek a fejlődés szempontjából megfelelő inklúziós elrendezések lehetőségének értékelését illetően, ez pedig segítséget jelent a kívánt eredmény elérésében." (Kontos, Moore és Giorgetti, 1998. 38. O.).

Ezt a nézőpontot - miszerint (az óvodai) integráció, inklúzió akár apró(nak tűnő), „mikro" momentumait is fontos megfigyelni, kiemelten hangsúlyosnak tartjuk, hiszen gyakran éppen ezeknek a mozzanatoknak a megragadásával, tudatosításával lehet a pedagógusoknak támogatást nyújtani az integrált helyzetben folytatott gondozó-nevelő munkájukban.

Kontos és munkatársai (1998) a korábban már említettekkel összhangban, kiemelik a korai interakciókban és tevékenységekben szerzett tapasztalatok fontosságát, és mindezek kontextusba ágyazottságát. A szerzők tanulmányukban egy olyan vizsgálatot mutatnak be, amelyet a fentiek megfontolásából végeztek el. Kutatásukban inkluzív óvodai csoportban figyelték meg a gyerekek és a pedagógusok viselkedését. Lássunk néhányat a vizsgálat eredményeiből. Az SNI gyerekek a szabad játék ideje alatt az idő nagy részében manipulatív vagy valamilyen nem játék jellegü, pl. kézműves tevékenységet végeztek, általában egy pedagógus jelenlétével kiegészült gyerekcsoportban. Ezzel szemben nem SNI gyerekeknél leggyakrabban szerepjátékot figyeltek meg (tehát olyan tevékenységet, aminek középpontjában a kommunikációs és társas készségek gyakorlása áll) és sok időt töltöttek egyedül a pedagógussal vagy egy társukkal (ami az SNI-sek között nem volt gyakori) (Kontos, Moore és Giorgetti, 1998).

File (1994) tanulmányában egy olyan vizsgálatról számol be, amelyben integrált nevelésben részesülő SNI és nem SNI gyereket figyeltek meg szabad játék során. $A$ kutatás célja az volt, hogy megvizsgálja a játékuk kognitív és szociális komplexitását, illetve a pedagógusokkal folytatott interakcióikat. A következőkben a megfigyelés módszertanából kiemeljük a kategóriarendszert, amit az interakciók megragadására alkalmaztak (Rubin, Maioni és Hornung (1976) nyomán, amelyben Parten és Smilansky (é.n.) munkáját adaptálták):

Elkülönítették a kognitív és a szociális játékot. Az előbbihez tartozott a funkcionális játék (egyszerű, ismétlődő mozdulatok tárgyakkal vagy azok nélkül); a konstruktív játék (tárgyakkal való manipuláció, hogy „alkosson” valamit) és a szerepjáték. A szociális játékba a komplexitás sorrendjében az alábbiak tartoztak:

- Magányos játék/solitary (egyedül játszik a játékokkal, a közelében levő gyerekektől eltérő játékot játszik);

- Párhuzamos/parallel játék (hasonló játékot játszik, mint a közelében levő gyerekek, de nincs interakció közöttük);

- Interaktív játék (verbális vagy nonverbális kontaktus van a gyerekek között, akik ugyanazt játsszák, vagy ugyanazokkal a játékokkal játszanak).

A gyermek-pedagógus interakciók megfigyelésére az alábbi kategóriákat alkalmazták:

- Nem vonódik be a pedagógus (nincs a pedagógus a közelben, vagy a közelben lévő pedagógus figyelmen kívül hagyja a megfigyelt gyermeket);

- Bevonódik a rutinba/nem a játékba (Részt vesz a megfigyelt gyerekkel nem játék tevékenységben, önkiszolgáló tevékenységben, párbeszédben, rutin tevékenységben);

- Figyel (nézi a gyereket, de nincs interakcióban a megfigyelt gyerekkel);

- Támogatja a kognitív játékot (interakcióban van a megfigyelt gyerekkel, fókuszban azzal, ahogy eszközöket, játékokat vagy ötleteket/reprezentációkat használ);

- Támogatja a szociális játékot (interakcióban van a megfigyelt gyerekkel, amelynél fókuszban a gyerek társaival folytatott interakciója van). 
Az utóbbi kettőnél megkülönböztettek indirekt és direkt formát aszerint, hogy a pedagógus irányítja az interakciót, vagy lehetőséget ad a gyermeknek, hogy ő irányítsa azt. Eszerint négyféle támogatási mód jöhet létre (a jobb érthetőség kedvéért az eredeti példákat is bemutatjuk):

- Kognitív játék direkt támogatása: az eszközök használatának meghatározása (pl. „Töltsd meg a csészét."). Zárt kérdések feltevése (egy konkrét válasszal pl. „Melyik a nagyobb?”).

- Kognitív játék indirekt támogatása: Nyitott kérdések feltevése (pl. Melyik színt fogod következőként használni?"), válasz a gyerek ötleteire, verbalizációira (pl. „Micsoda helyes autót készítettél.").

- Szociális játék direkt támogatása: a gyerek szerepének átvétele (pl. „Seth szeretne veled játszani.") vagy a gyereknek felhasználandó stratégiára példát mond (pl. „Mondhatnád, hogy ,Én szeretnék következni, Aurelia.”).

- Szociális játék indirekt támogatása: ,jelek”, „nyomok” azonosítása (PI. „Szerintem nem hallott téged."), nyitott kérdések kérdezése (pl. Mit tehetnél, ha szeretnél játszani?”.), vagy implicit emlékeztetők adása (pl. „Ki kellene találnod, hogy erre hogyan jöhetnél rá.").

A fentiekből látható, hogy a kutatók milyen mozzanatokra bontották le a viselkedést, és hogyan sikerült ezáltal egy megbízható kategóriarendszert létrehozniuk.

File (1994) röviden a következőket emeli ki a csoportban történt megfigyelés eredményeiből: a pedagógusok játéktámogatása irányítóbb volt a kognitív játékban az SNI gyerekek esetében, mint a nem SNI-seknél, még ha a kognitív játék fejlettségi szintjének átlagában meg is egyeztek. A szociális játék támogatására összpontosító pedagógus-gyerek interakciók relatíve ritkának bizonyultak, illetve a szociális játék szintjének átlagában mutatott különbségek ellenére egyformának mutatkoztak a két összehasonlított gyerekcsoportban. Érdekes továbbá, hogy a pedagógusok jellemzően inkább a játék kognitív aspektusát támogatták - szemben a szociálissal -, annak ellenére, hogy a vélekedéseik vizsgálatakor az derült ki, hogy úgy gondolják, az SNIsek társas készségek terén elmaradnak nem SNI társaikhoz képest (File, 1994).

Bemutatjuk egy másik, File kutatásához hasonló megfigyeléses vizsgálat módszertanát. Harper és McCluskey $(2002,2003)$ megfigyeléses vizsgálataikban az interakciók további aspektusait vizsgálták. A viselkedések leírására a következő kategóriarendszert használták. Meghatározták a gyerek helyzetét és/vagy tevékenységét (ezt önmagában nem vizsgálták, csak ha a változás kezdeményezőinek meghatározásához kapcsolódtak); hogy ki kezdeményezte a tevékenységet (a megfigyelt gyerek, társ, felnőtt vagy a felnőtt-gyerek csoport) és a szociális részvétel szintjét. Azt is megfigyelték, hogy a tevékenységben bekövetkezett változás elindítója ki: a fókuszban lévő gyermek, társ, felnőtt vagy a csoport. A szociális részvétel szintjénél Parten (1932, idézi Harper és McCluskey, 2002, 2003) osztályozását vették át. A fenti, File (1994) vizsgálatában említett három kategória szintén megjelenik: magányos játék, párhuzamos játék és interakció,ez utóbbiba beleértik a felnőttel való interakciót is. (A szociális interakciókon belül megkülönböztettek csak társakkal, csak felnőttel és társ(ak)kal, és felnőttel is folytatott (azaz csoport) interakciókat. Ennél a megfigyelésnél egy negyedik kategóriát is találunk, a szemlélődő/,onlooker” viselkedést (ez az az eset, amikor a gyermek áll interakcióban másokkal, de nyilvánvalóan mások tevékenységeinek nézésével foglalja el magát) (Harper és McCluskey, 2002, 2003).

Két érdekes momentumot emelünk ki a szerzők (Harper és McCluskey, 2002) eredményeiböl :

Az egyik fontos szempont a nyelv volt. Azok, akik nem vagy alig voltak képesek használni, inkább egyedül voltak, és ritkán (akkor is a többiekéhez képest eltérő straté- 
A megfigyelés kutatásmódszertana - interakciók megfigyelése integrált és inkluzív óvodai környezetben giával) kezdeményeztek interakciót. A másik tényező a helyváltoztatás függetlenségéé volt: azok a gyerekek, akik nem voltak képesek erre, mind a tevékenységek, mind a szociális „váltások” terén a felnőttől függtek.

Ugyanezen szerzők egy másik, szintén inkluzív óvodai környezetben végzett vizsgálatának az volt a célja, hogy azt a jelenséget igyekezzenek feltárni, miszerint negatív korreláció tapasztalható a gyerekek felnőttel folyó és társakkal folyó interakciói között. A 3-4 évesek körében végzett megfigyelésük eredményeként úgy találták, hogy a 24-böl 21 gyermek esetében negatívan korrelált a felnőttel és a társakkal töltött idő. További eredményük volt, hogy a felnőtteknél megjelentek a szándékukon kívüli interakciók: a pedagógusok a vártnál gyakrabban kezdeményeztek véletlenül interakciót egyedül lévő gyermekkel, és kevésbé voltak hajlamosak ezt tenni, amikor egy gyermek interakcióban állt egy társával. Érdekes, a pedagógia oldaláról is megfontolandó eredményük volt, hogy ha felnőtt interakciót kezdeményezett a gyerekekkel, ők utána inkább a felnőttel kezdeményeztek egy következőt, kevésbé a társukkal. A cikkük címében fel is teszik a kérdést: „Vajon a pedagógusok gátolják a társakkal folytatott interakciókat?" (Harper és McCluskey, 2003).

Kutatásuk korlátainak ismertetése mellett mind az elmélet, mind a kapcsolódó nevelési tervezéssel kapcsolatban megfogalmaznak implikációkat a szerzők. „Az elméletet oldaláról fontos lesz meghatározni, hogy melyek azok a felnőtt viselkedések, amelyek akadályozzák a következő nyitást a társak felé, és melyek azok (ha nem ugyanazok azok), amelyek támogatják azt a felnőtt irányába. Illetve azt is fontos meghatározni, hogy vajon ezek a hatások kontextusfüggőek-e. Az ilyen információk segíteni fognak abban, hogy tisztázhassuk a kapcsolatot a társakkal, illetve a felnőttekkel folytatott szociális interakciók között, és azt, hogy ezek hogyan változnak az idők során... A gyakorlat oldaláról tekintve ennek az elkülönítése fontos lesz azon a téren, hogy segítsen a pedagógusoknak elkerülni a spontán kortárs kapcsolatok nem szándékos akadályozását. Abban is segíthetnek, hogy jobban meg lehessen tervezni, hogy egyáltalán közbeavatkozzanak-e, ha igen, mikor és milyen kontextusban tegyék, hogy támogassák az óvodások szociális készségeit, és hogy facilitálják különösen az SNI gyerekek teljes szociális inklúzióját..." (Harper és McCluskey, 2003. 181. o.).

Áttekintve az óvodai inklúziót érintő megfigyeléses vizsgálatokról szóló tanulmányokat, elmondható, hogy az inklúziót általános, többféle SNI gyermeket is megfigyelő vizsgálatokon (Id. fent) túl találunk olyanokat is, amelyek nagy minta elemzésével igyekeznek átfogó képet rajzolni (pl. Brown, Odom, Li és Zercher, 1999). Emellett találkozunk olyan megfigyeléses vizsgálatokkal, amelyek egy-egy SNI típus esetében tanulmányozzák a gyerekek interakcióit pl. hallássérült gyerekek kommunikációs készségét vizsgáló megfigyelés (Bobzien, Richels, Raver, Hester, Browning és Morin, 2013) vagy a specifikus nyelvi zavarral küzdő gyermekek interakcióinak megfigyelése és összevetése a szülő és pedagógus általi jellemzéssel (McCabe és Marshall, 2006).

\section{A csoportszoba környezetének elemzése, hatása az integrációra, inklúzióra}

A szúkebb értelemben vett interakciók vizsgálása mellett a tágabb interakciók, azaz a környezet tanulmányozása is jelentőséggel bírhat az integráció, inklúzió elemzése szempontjából.

Az óvodai társas környezeten túl a fizikai környezet általában véve is kiemelt jelentőséggel bír a gyerekek fejlődése szempontjából. Egy csoportszoba áttekintésekor elkülöníthetjük az egyes játéktereket (pl. „alaprajzok” rajzolásával és elemzésével), és elemezhetjük, hogy a gyerekek mely tevékenységformáihoz kapcsolódnak az egyes 
terek, illetve milyen igényeket, szükségleteket (pl. biztonság) elégítenek ki (vö Dúll, 2015). Vizsgálhatjuk az egyes játéktereket olyan szempontból is, hogy pl. szabad játék során milyen spontán tanulási, tapasztalatszerzési lehetőségeket nyújtanak a gyerekek számára (B. Lakatos és Böddi, 2015).

Tehát maga a környezet, a tér is hatással van a gyerekek és felnőttek viselkedésére, interakcióira, akár azzal, hogy elősegíti azokat. A társas interakciók serkentése nem csak közvetlen (pl. célzott beavatkozással, játékok ,játszatásával”), hanem közvetett módon is törtéhet azáltal, ahogy a fizikai teret (pl. csoportszobát) strukturáljuk. A fizikai környezet megfelelő alakítása, a játékterek és játéktevékenységek befolyásolása (pl. nagyobb asztalt többen tudnak körbeülni) hatással lehet a társas kapcsolatokra. A játékeszközök jellege - inkább társas vagy elszigetelt tevékenységet motivál - is hatással van az interakciókra (Beckman és Kohl, 1984, idézi F. Lassú, 2007), és ugyanez igaz szabadtéri játékkörnyezetekre is (Dúll, 2003).

Tehát az SNI gyerekek társas kapcsolatainak fejlesztése terén használhatjuk azokat az aspektusokat, amiket a fizikai környezet kínál. „Azok a játékeszközök, amelyek hatékonyak abban a tekintetben, hogy „előcsalják” és támogassák a szociális játékot, egy olyan visszafogott tanítási-nevelési eszközt adhatnak a pedagógusok kezébe, amely szépen belevegyül az inkluzív csoportok mindennapi játéktevékenységeibe" (Ivory és McCollum, 1999. 238. o.).

Ivory és McCollum (1999) kutatásukban a szociális és izolációs játék hozzáférhetőségét variálták a négy hetes vizsgálati idő alatt működő inkluzív óvodai csoportban. Azt vizsgálták, hogy hogyan változik az inkluzív közegben nevelt SNI gyerekek szociális játékának szintje attól függően, hogy szociális vagy izolációs játékokkal találkoznak. Szociális játékoknak az alábbiakat tekintették: építőkockák, beöltözős ruhák, babák, babaház, háztartási eszközök, bábok, jármüvek. Izolációs játékok a következök voltak: gyurma, Lego, könyvek, festék, ecsetek, papír, olló, zsírkréták és filctollak, kirakók. Eredményeikből kiemeljük, hogy a szociális játék „feltételben” szignifikánsan gyakrabban jelent meg a kooperatív játék. Az elszigetelt játék ritka volt mindkét esetben. Érdekes volt az az eredmény, hogy kooperatív játék ritkán történt izolációs játékokkal. A szerzők felhívják a figyelmet arra, hogy a környezet tudatos alakításával a pedagógusok például befolyásolhatják a csoportjukban megvalósuló játékot (Ivory és McCollum, 1999).

A játékszerek szociális „felhívó jellegén túl” más tényezőik is hatnak a társas interakciókra. Ilyen például a csoportméret, amelyet megkívánnak (vö Dúll, 2015). A kiscsoportos játékot „hívó” tér és játékeszközök intenzívebb interakciókhoz vezetnek, szemben a párban vagy nagy csoportban játszhatókkal (F. Lassú, 2007).

A játékterek és eszközök jellegén túl a belmagasság is befolyásolja, hogy milyen tevékenységek jelennek meg az adott környezetben. A nagyobb belmagasság aktívabb játékra ösztönöz, míg az alacsonyabb csendesebb játékra (Weinstein- David, 1987, idézi Dúll, 2009). A csoportszobai játékterek kialakításánál tekintettel kell lennünk az ott végzett tevékenységek térigényére és az ún. ambiens, vagyis nehezen tudatosuló környezeti ingerekre is, mint a zajszint, a hömérséklet, páratartalom és a különböző szagok is, melyek mind befolyásolhatják a viselkedést (Dúll, 2009). A zajszint kapcsán érdemes megemlíteni, hogy ennek különösen fontos szerepe van interakcióval foglalkozó kutatásokban, mivel a zaj az interakció minőségét is befolyásolja. Kutatások igazolták, hogy zajban a tanárok rövidebb mondatokban fogalmaznak, beszédtempójuk lelassul, fogalmazásuk egyszerüsödik, hangszínük monotonná válik. (Téglás, 2004). Szintén a fizikai elrendezés befolyásolhatja az interakciók megjelenésének gyakoriságát az ún. szociopetális vagy szociofugális elrendezéssel. A szociopetális elrendezés kedvez az interakciónak pl. egymás felé fordított székek, puffok, babzsákfotelek, míg a 
A megfigyelés kutatásmódszertana - interakciók megfigyelése integrált és inkluzív óvodai környezetben

szociofugális elrendezés gátolja az interakciók megjelenését pl. egymástól távol elhelyezett asztalokkal, székekkel, vagy az iskolákból jól ismert padsoros, oszlopos elrendezéssel (Dúll, 2009). A fizikai környezet jellemzőin túl hangsúlyos még az időkeret, vagyis az az idő, amelyet szabad játékkal tölthetnek az óvodások, hiszen megfelelő időt kell biztosítani az együttmüködéshez és feladatmegoldáshoz ( $F$. Lassú, 2007).

Összegezve az óvodai inklúzió kapcsán fent leírtakat, elmondhatjuk, hogy a fenti kutatások is mutatják, hogy milyen sok, pedagógiai szempontból is hasznosítható tanulsággal szolgálhat az óvodai interakciók vizsgálata, hiszen az interakciók arányának feltérképezése árnyaltabbá teheti nemcsak a kutató, hanem a pedagógusok számára is a csoport társas kapcsolatairól kialakult képét. Mivel az interakciók bizonyos aspektusai lehetnek nem tudatosak, nem szándékosak, a megfigyelések rávilágíthatnak ezekre is, ezzel növelve a pedagógus tudatosságát a kommunikációja terén is. $A$ kontextus szempontját beemelő áttekintésből pedig az látható, hogy a csoportszoba környezete milyen sok tényezőt tekintve lehet hatással az SNI és nem SNI gyerekek viselkedésére, interakcióira. Mindezek tudatos átgondolása lehetőséget nyújthat a pedagógusok és a gyermekekkel foglalkozó más szakemberek számára is, hogy például a környezeti elrendezéssel fokozzák a csoportba járó - SNI és nem SNI - gyerekek társas interakcióit, befolyásolják a játszott játékok társas aspektusát.

A sikeresen, „olajozottan” működő integráló, inkluzív nevelési helyzetek megfigyelésével, majd a tapasztaltak elemzésével olyan jó gyakorlatokhoz juthatunk, amelyet más integráló nevelésben dolgozó szakemberek is hasznosíthatnak.

\section{Zárás}

Írásunk elején a kutatási stratégiák lényegi jellemzőiből kiindulva mutattuk meg, hogy a megfigyelés módszerének van létjogosultsága a tudományos vizsgálatokban. Öszszegeztük, hogy általában mire kell figyelni a megfigyeléssel végzett kutatások tervezése, megvalósítása során, hogyan lehet biztosítani az érvényességet és a megbízhatóságot, csökkenteni a szubjektivitást.

A továbbiakban példákon keresztül megmutattuk, hogy a megfigyelés módszerét milyen széleskörüen lehet alkalmazni a gyerekek viselkedésének tanulmányozásában. Az ökológiai, környezetpszichológiai megközelítés szempontjai a viselkedés tágabb kontextusban való elemzéséhez segítenek bennünket. Az óvodai integrációval foglalkozó külföldi kutatások jól illusztrálják, hogy a megfigyelés alkalmazása milyen kulcsmozzanatok megértését teszi lehetővé az inklúzió gyakorlatának eredményessége és hatása vonatkozásában.

A bemutatott empirikus munkák is bizonyítják, hogy sokféle kutatási probléma, kérdés esetén érdemes ezt a módszert választani nehézségei ellenére is. Reméljük, hogy olvasóink ezután bátrabban alkalmazzák a megfigyelést akár kutatásukban, akár pedagógiai munkájuk tudatosabb elemzésében, tényeken alapuló fejlesztésében.

\section{Köszönetnyilvánítás}

Köszönetet mondunk B. Lakatos Margitnak, Bertalan Györgynek és Hámornik Balázsnak a tanulmány megírása során nyújtott hasznos észrevételeikért. 


\section{Irodalom}

2011. évi CXC. törvény a nemzeti köznevelésröl

URL: http://net.jogtar.hu/jr/gen/hjegy_doc.cgi?docid=A1100190.TV\#lbj1param (letöltve: 2015. 08. 11.)

B. Lakatos Margit és Böddi Zsófia (2015): Gyakorlatok a Játék pszichológiája, pedagógiája és módszertana szemináriumaira. Oktatói segédanyag. ELTE TÓK, Budapest, TÁMOP 4.1.2.B.2-13/1-2013-0007 „Országos koordinációval a pedagógusképzés megújításáért”. URL: http://tamop2014.tok.elte.hu/dok/szakmai_anyagok/gyakorlati_kepzes_ megujitasahoz/ovo/Lakatos_Boddi_2015_Gyakorlatok_a_jatek_pszichōogiaja_ pedagogiaja_es_modszertana_szemminariumra.pdf (letöltve: 2015.08 .11 .)

Babbie, E. (2003): $\bar{A}$ társadalomtudományi kutatás gyakorlata. Balassi Kiadó, Budapest.

Bobzien, J., Richels, C., Raver, S. A., Hester, P., Browning, E. és Morin, L. (2013): An Observational Study of Social Communication Skills in Eight Preschoolers with and Without Hearing Loss During Cooperative Play. Early Childhood Education Journal, 41. 339-346.

Booren, L. M., Downer, J. T. és Vitiello, V. E. (2012): Observations of Children's Interactions with Teachers, Peers, and Tasks across Preschool Classroom Activity Settings. Early Education and Development, 23. 517-538.

Böddi Zsófia és B. Lakatos Margit (2010): Vackor nyomában - Vallomások az óvodáról, az óvodai közösségröl. Kisgyermekek, nagy problémák, 22. kiegészítő kötet, 2010. április. Raabe Tanácsadó és Kiadó Kft., 1-20.

Brown, W. H. , Odom, S. L., Li, S. és Zercher, C. (1999): Ecobehavioral Assessment in Early Childhood Programs: A Portrait of Preschool Inclusion. The Journal of Special Education, 33. 3. 138-153.

Bussmann, J. B. J és Ebner-Priemer, U. W. (2014): Ambulatory Assessment of Movement Behavior In: Mehl, M R. és Conner, T. S. (2014, szerk.) Handbook of Research Methods for Studying Daily Life. The Guliford Press, New York, London, 235-250.

Cole, M. és Cole, S. R. (2003): Fejlődéslélektan. Osiris Kiadó, Budapest.

Dúll Andrea (2001): A környezetpszichológia története. Magyar Pszichológiai Szemle, 2. 287-328.

Dúll Andrea (2002): Ember és környezet affektív kapcsolata: a helykötődés. Alkalmazott Pszichológia, 4. 2. 49-65.

Dúll Andrea (2003) Kültéri játékkörnyezetek környezetpszichológiai elemzése. Alkalmazott Pszichológia, 5. 1. 59-76.

Dúll Andrea (2009): A környezetpszichológia alapkérdései: Helyek, tárgyak, viselkedés. L'Harmattan, Budapest.

Dúll Andrea (2015): A bölcsőde környezetpszichológiája. In Gyöngy Kinga (szerk.) Első lépések a müvészetek felé. A vizuális nevelés és az anyanyelvi-irodalmi nevelés lehetöségei kisgyermekkorban. DialógCampus Kiadó, Budapest. 265-297.

Dúll Andrea és Urbán Róbert (1997): Az épített környezet konnotatív jelentésének vizsgálata: módszertani megfontolások. Pszichológia 17. 2. 151-179.

F. Lassú Zsuzsa (2007): A kortárskapcsolatok és a társas kompetencia fejlesztése az integrált nevelésben. In: Bollókné Panyik llona (szerk.): Gyermek - Nevelés - Pedagógusképzés, Trezor Kiadó, Budapest, 137-147.

Falus Iván (2004): A megfigyelés. In: Falus Iván (szerk): Bevezetés a pedagógiai kutatás módszereibe. Müszaki Könyvkiadó Budapest. 125-170.

File, N. (1994): Children's Play, Teacher-Child Interactions, and Teacher Beliefs in Integrated Early Childhood Programs. Early Childhood Research Quarterly, 9. 223-240.

Franchak, J. M., Kretch, K. S., Soska K. C. és Adolph, K. E. (2011): Head-Mounted Eye Tracking: A New Method to Describe Infant Looking. Child Development, 82. 6. 1738-1750.

Gardner, F. (2000): Methodological Issues in the Direct Observation of Parent - Child Interaction: Do Observational Findings Reflect the Natural Behavior of Participants? Clinical Child and Family Psychology Review, 3. 3. 185-198.

Goodwin, M. S. (2014): Passive Telemetric Monitorng: Novel Methods for Real-World Behavioral Assessment In: Mehl, M R. és Conner, T. S. (2014, szerk.) Handbook of Research Methods for Studying Daily Life. The Guliford Press, New York, London, 251-266. 
A megfigyelés kutatásmódszertana - interakciók megfigyelése integrált és inkluzív óvodai környezetben

Harper, L. V. és McCluskey, K. S. (2002): Caregiver and peer responses to children with language and motor disabilities in inclusive preschool programs. Early Childhood Research Quarterly, 17. 148-166.

Harper, L. V. és McCluskey, K. S. (2003): Teacher-child and child-child interactions in inclusive preschool settings: do adults inhibit peer interactions? Early Childhood Research Quarterly, 18. 163-184.

Hektner, J. M (2014): Developmental Psychology In: Mehl, M R. és Conner, T. S. (2014, szerk.) Handbook of Research Methods for Studying Daily Life. The Guliford Press, New York, London, 585-600.

Héra Gábor és Ligeti György (2014): Módszertan. Bevezetés a társadalmi jelenségek kutatásába. Osiris Kiadó, Budapest.

Ivory, J. J. és McCollum, J. A. (1999): Effects of Social and Isolate Toys on Social Play in an Inclusive Setting. The Journal of Special Education, 32. 4. 238-243.

Kasza Georgina (2008): Módszertani megjegyzések a kutatásról. In: Kőpatakiné Mészáros Mária (szerk.): A küszöbön. Sajátos nevelési igényü gyerekek az óvodákban. Fogyatékos Személyek Esélyegyenlöségéért Közalapítvány, Budapest.

Keményné Pálffy Katalin (2006): Alapozó pszichológia. Nemzeti Tankönyvkiadó, Budapest

Kontos, S., Moore, D. és Giorgetti, K. (1998): The Ecology of Inclusion. Topics in Early Childhood Special Education, 18. 1. 38-48.

Kósáné Ormai Vera (2001): A mi óvodánk. Neveléspszichológiai módszerek az óvodában. Okker, Budapest.

Kósáné Ormai Vera, Járó Katalin és Kalmár Magda (1975): Fejlődéslélektani vizsgálatok. Társas kapcsolat és személyiség. Tankönyvkiadó, Budapest.

Kőpatakiné Mészáros Mária (2004): Közben felnő egy elfogadó nemzedék. Új Pedagógiai Szemle, 2004 február, 38-48.

URL: http://www.ofi.hu/tudastar/kopatakine-meszaros (letöltve: 2015. 08. 11.)

Kőpatakiné Mészáros Mária (2008) (szerk.): A küszöbön. Sajátos nevelési igényü gyerekek az óvodákban. Fogyatékos Személyek Esélyegyenlőségéért Közalapítvány, Budapest.

Kürti Istvánné és Szilágyi Lilla (1970): Új személyiségvizsgáló módszer óvodások és alsó tagozatos iskolások számára. Akadémiai Kiadó, Budapest.

Li, S., Marquart, J. M. és Zercher, C. (2000): Conceptual Issues and Aanalytic Strategies in Mixed-Method Studies of Preschool inclusion. Journal of Early Intervention, 23. 2. 116-132.

Lytton, H. (1971): Observation studies of parent-child interaction: a methodological review. Child Development, 42. 3. 651-684.

McCabe, P. C. és Marshall, D. J. (2006): Measuring the Social Competence of Preschool Children With Specific Language Impairment: Correspondence Among Informant Ratings and Behavioral Observations. Topics in Early Childhood Special Education, 26. 4. 234-246.

Mehl, M. R. és Robbins, M. L (2014): Naturalistic Observation Sampling: The Electronically Activated Recorder (EAR) In: Mehl, M R. és Conner, T. S. (2014, szerk.) Handbook of Research Methods for Studying Daily Life. The Guliford Press, New York, London, 176-192.

Mérei Ferenc (1989): Társ és csoport. Akadémiai Kiadó, Budapest.

Mérei Ferenc (2004): Közösségek rejtett hálózata. Osiris Kiadó, Budapest.

Mérei Ferenc és V. Binet Ágnes (2006): Gyermeklélektan. Medicina Könyvkiadó Rt., Budapest.

Mönks, F. J. és Knoers, A. M. P. (2004): Fejlődéslélektan. Urbis Könyvkiadó, Budapest.

Odom, S. L. (2000): Preschool Inclusion. What We Know and Where We Go From Here. Topics in Early Childhood Special Education, 20. 1. 20-27.

Pálfi Sándor (é.n.) Az óvodai játék környezetkultúrája. URL: http://www.oki.hu/oldal.php?tipus=cikk\&kod=ovodai-Palfiovodai (letöltve: 2015. 01. 28.).

Sántha Kálmán (2006): Mintavétel a kvalitatív pedagógiai kutatásban. Gondolat Kiadó, Budapest.

Sántha Kálmán (2007): A kvalitatív metodológiai követelmények problémái. Iskolakultúra, 6-7. 168-177.

Sántha Kálmán (2009): Bevezetés a pedagógiai kutatás módszertanába. Eötvös József Könyvkiadó, Budapest. 
Böddi Zsófia - Keszei Barbara - Serfőző Mónika - Dúll Andrea

Szabolcs Éva (2001): Kvalitatív kutatási metodológia a pedagógiában. Műszaki Könyvkiadó, Budapest.

Szokolszky Ágnes (2004): Kutatómunka a pszichológiában. Metodológia, módszerek, gyakorlat. Osiris Kiadó, Budapest.

Téglás Zsolt (2004): Iskolai zajártalmak. Új Pedagógiai Szemle, 11. 122-126.

Wilhelm, P., Perrez, M. és Pawlik, K (2014): Conducting Research in Daily Life: A Historical Review In: Mehl, M R. és Conner, T. S. (2014, szerk.) Handbook of Research Methods for Studying Daily Life. The Guliford Press, New York, London, 62-86. 